\title{
Embedding strength of fully-threaded dowel-type fasteners in cross-laminated timber: an experimental study
}

\author{
Bruna Bernardi Maia ${ }^{1}$, José Luiz Miotto ${ }^{1}$,
} Jorge Luís Nunes de Góes ${ }^{2}$

\author{
${ }^{1}$ Universidade Estadual de Maringá - UEM, Av. Colombo, 5790, Zona sete, CEP 87.020-900, Maringá, PR, Brasil. \\ ${ }^{2}$ Universidade Tecnológica Federal do Paraná - Campus Campo Mourão, R. Rosalina Maria Ferreira, 1233, Vila Carola \\ CEP 87301-899, Campo Mourão, PR, Brasil. \\ e-mail: brunabernardimaia@gmail.com,jlmiotto@uem.br,jgoes@utfpr.edu.br
}

\begin{abstract}
The purpose of this paper is to experimentally evaluate the embedding strength of dowel-type fasteners in Cross-Laminated Timber (CLT), observing the effect of lamellae orientation and the dowel diameters. Thereby, CLT specimens - with three layers of lamellae - and solid timber specimens were produced and tested under loads at $0^{\circ}$ and $90^{\circ}$ with the direction of the grain, considering five dowel diameters. The results showed that CLT embedding strength depends on the dowel diameter in the two investigated directions. The CLT embedding strength parallel to the grain was up to $8 \%$ lower than those for solid timber in the same direction, and up to $26 \%$ higher than the solid timber strength in the perpendicular direction. The analysis of variance (ANOVA) showed no significant difference between the mean values of the CLT and solid timber embedding strengths, except for the embedding strength perpendicular to the grain found for $16 \mathrm{~mm}$ dowel diameter. When comparing the results obtained experimentally with those determined analytically, the equation proposed by KENNEDY et al. (2014) led to a better agreement, for both the loads applied at $0^{\circ}$ and $90^{\circ}$ to the grain direction.
\end{abstract}

Keywords: Cross-laminated Timber; Dowelled connections; Embedment strength; Half-hole embedment tests; Design approaches.

\section{INTRODUCTION}

Cross-laminated timber (CLT) is a wood construction system gaining more and more space in the world market. In recent years, CLT has become one of the most important construction products in wood engineering [1]. The global volume produced annually is expected to be 1.25 million $\mathrm{m}^{3}$ by 2020 [2]. Nowadays, according to AMORIN et al. [3], the countries leading the use of CLT are Austria, Germany, Switzerland, Sweden, Norway and the United Kingdom.

CLT structural panels are commonly composed by an odd number of sawn timber layers, bonded orthogonally to each other. The cross lamination provides a material homogenization, resulting in panels with relatively better mechanical properties than lumber and able to resist in-plane and out-of-plane loading [4-6].

However, the structural performance of CLT constructions is related to the behavior of their connection systems. Extensive research has shown proper ductile behavior of mechanical connectors such as nails, screws, smooth dowels and angle brackets when used in CLT panel connections [7-15]. Mastering the parameters that govern the connection behavior is necessary to achieve safe and efficient design.

Several normative documents follow the European Yield Model (EYM) to determine the load-carrying capacity of connections with dowel-type fasteners. This design model is based on Johansen's yield theory [16], wherein the main parameters are the value of the embedding strength and the yield moment of the fasteners.

The embedding behavior of solid timber has been studied by several researchers and empirical equations to determine the due strength have been adopted by normative documents. It is noted that the embedding strength is influenced by several factors. The analytical formulas presented in normative documents only consider the influence of wood density, dowel diameter and the angle between the load and the grain. Researches also show the influence of wood moisture [17, 18], roughness [19] and hardness [20] of the dowel. 
There are contradictions about the influence of dowel diameter on embedding strength in the parallel to the grain direction. The analytical formulas proposed in EN 1995-1-1 [21] are based on research carried out by WHALE, SMITH and LARSEN [22] and EHLBECK and WERNER [23], and they consider the wood density and dowel diameter for loads in parallel and perpendicular directions to the grain. Analytical formulas presented in NDS standard [24] are based on Wilkinson's research [25], and consider the influence of the dowel diameter only for loads in the perpendicular direction to the grain, and also consider the influence of wood density. SAWATA and YASUMURA [26] and SANDHAAS et al.[20] conducted embedding tests, and like WILKINSON [25], they concluded that the embedding strength parallel to the grain is little influenced by the dowel diameter.

Due to the anisotropic nature of the wood, the embedding deformation depends on the inclination betwenn the compression forces and the grain. The results of EHLBECK and WERNER [23] and BLERON and DUCHANOIS [27] showed that as greater the angle between the embedding strength and the grain, lower the embedding strength.

Based on the above, the embedding behavior of CLT is relatively more complex than the solid timber due to the different orientations of the grain in each layer, layers with different thickness, the presence of glue between the lamellae and potential presence of gaps between longitudinal lamellae. Therefore, research has been carried out to develop equations that express the CLT embedding strength for dowel type-fasteners positioned in the perpendicular plane of the panel or in the edge.

In this context, the objective of this research is to analyze the embedment strength of CLT and provide a better understanding regarding the CLT embedding behavior. For this purpose, CLT and solid timber embedding tests were performed, including specimens loaded under $0^{\circ}$ and $90^{\circ}$ to the grain direction (that will be referred during the discussion as direction 1 and direction 2, respectively), and adopting five different dowel diameters. A comparison between the experimental embedding strength of CLT and analytical results obtained according to empirical equations developed for CLT proposed in the literature is also presented.

\section{EXISTING APPROACHES FOR THE CLT EMBEDMENT STRENGTH}

Initial research on the CLT embedding strength was conducted in Germany by BLASS and UIBEL [28] and Uibel and Blass [29, 30].After, KENNEDY et al. [31], in Canada, and DONG et al. [14, 32, 33], in China/Canada, also researched the topic. Several embedment tests on CLT specimens were accomplished in these research projects, and based on the experimental results, the authors developed empirical equations to determine the embedment strength. In order to compare the experimental results of this research with results obtained through the equations proposed by those authors, we briefly present which parameters were adopted in their research.

\subsection{Blass and Uibel approach}

BLASS and UIBEL [28] conducted 620 tests to determine the embedment strength of dowel-type fasteners positioned in the plane side of CLT panel, according to EN 383. The tests were performed using dowels, screws and nails, loaded under $0^{\circ}, 45^{\circ}$ and $90^{\circ}$ to the grain of outer layers. The mean density of tested CLT panels was between $445 \mathrm{~kg} / \mathrm{m}^{3}$ and $471 \mathrm{~kg} / \mathrm{m}^{3}$. Table 1 summarizes some parameters of these tests.

Table 1: Test configurations adopted by BLASS and UIBEL.

\begin{tabular}{|c|c|c|c|}
\hline \multicolumn{2}{|c|}{ FASTENERS } & \multirow[b]{2}{*}{ CLT BUILD-UP (mm) } & \multirow[b]{2}{*}{ LOADING ANGLE (ํ) } \\
\hline TYPE & DIAMETER (mm) & & \\
\hline \multirow{3}{*}{ Dowel } & \multirow{3}{*}{24} & $17-17-17-17-17$ & $0 ; 90$ \\
\hline & & $19-40-19$ & $0 ; 45 ; 90$ \\
\hline & & $8.5-7.5-10-7.5-8.5$ & 0 \\
\hline \multirow{2}{*}{ Dowel } & \multirow{2}{*}{20} & $17-17-17-17-17$ & $0 ; 45 ; 90$ \\
\hline & & $8.5-7.5-10-7.5-8.5$ & $0 ; 90$ \\
\hline \multirow{3}{*}{ Dowel } & \multirow{3}{*}{16} & $19-22-19$ & $0 ; 90$ \\
\hline & & $5.3-6.4-5.3$ & $0 ; 90$ \\
\hline & & $4.5-4.8-6.5-4.8-4.5$ & $0 ; 45 ; 90$ \\
\hline Dowel & 12 & $3.5-5-3.5$ & 0 \\
\hline
\end{tabular}




\begin{tabular}{cccc}
\hline Dowel & 8 & $3.5-5-3.5$ & 0 \\
\hline Screw & 12 & $5.3-6.4-5.3$ & $0 ; 90$ \\
\hline Screw & 8 & $3.5-5-3.5$ & $0 ; 45 ; 90$ \\
\hline Nail & 6 & $3.5-5-3.5$ & 0 \\
\hline Nail & 4.2 & $3.5-5-3.5$ & $0 ; 45 ; 90$ \\
\hline
\end{tabular}

Source: Adapted from BLASS and UIBEL [28]

From 438 test results with dowel fasteners, the authors developed two models for the embedment strength derived by a multiple regression analysis. Model 1 (Eq. 1) is independent of the CLT layup, whereas the model 2 (Eq. 2) takes this into account.

$$
\begin{aligned}
& \mathrm{f}_{\mathrm{h}, \text { pred, } \alpha}=\frac{0,035 \cdot(1-0,015 \cdot \mathrm{d}) \cdot \rho^{1,16}}{1,1 \cdot \operatorname{sen}^{2} \alpha+\cos ^{2} \alpha}(\mathrm{MPa}) \\
& \mathrm{f}_{\mathrm{h}, \text { pred, } \alpha}=0,032 \cdot 1-0,015 \cdot \mathrm{d} \cdot \rho^{1,20} \frac{\mathrm{n}_{\mathrm{i}=1}^{\mathrm{n}} \mathrm{t}_{0, \mathrm{i}}}{\mathrm{t} \cdot\left(1,6 \cdot \operatorname{sen}^{2} \alpha+\cos ^{2} \alpha\right)}+\frac{\mathrm{j}_{\mathrm{j}=1} \mathrm{t}_{90, \mathrm{j}}}{\mathrm{t} \cdot\left(1,6 \cdot \cos ^{2} \alpha+\operatorname{sen}^{2} \alpha\right)}(\mathrm{MPa})
\end{aligned}
$$

Where: $d=$ dowel diameter, in $\mathrm{mm} ; \rho=$ density of CLT panel; $t_{0, i}=$ thickness of the layer " $i$ " aligned to the outer layers; $t_{90, j}=$ thickness of the layer " $j$ " perpendicular to the outer layers; $t=$ total thickness of CLT. The validity of both models is limited to CLT with layers thinner than $40 \mathrm{~mm}$ and a build-up ratio $\sum \mathrm{t}_{0, \mathrm{i}} / \sum \mathrm{t}_{90, \mathrm{i}}$ between 0.95 and 2.1 .

From the test results with screws and nails, BLASS and UIBEL [28] proposed a model to determine embedment strength, which is limited to CLT with layers thinner than $9 \mathrm{~mm}$. For this reason, this model is not comparable with the experimental data. In cases of connections in CLT with layers of more than $9 \mathrm{~mm}$ in thickness using screws and nails, UIBEL and BLASS [34] suggest that the embedment strength can be calculated as for solid timber.

\subsection{Kennedy et al. approach}

KENNEDY et al. [31] carried out 1080 tests in CLT specimens, with 3 and 5 layers, according to ASTM D5764-97a [35] half-hole test method. The fasteners were positioned perpendicular to CLT panel and loaded under $0^{\circ}, 45^{\circ}$ and $90^{\circ}$ to the grain of outer layers. The tests were performed with lag screws, with diameters ranging from $6.35 \mathrm{~mm}(1 / 4$ ") to $19.1 \mathrm{~mm}(3 / 4$ "), and self-drilling screws with diameters of $6 \mathrm{~mm}, 8 \mathrm{~mm}$ and $12 \mathrm{~mm}$. The oven-dry density of tested CLT panels was between $350 \mathrm{~kg} / \mathrm{m}^{3}$ and $550 \mathrm{~kg} / \mathrm{m}^{3}$. From the results, a nonlinear regression analysis was performed to develop an equation for the embedment strength (Eq. 3), independent of the CLT layup and fastener diameter.

$$
f_{h, \text { avg, } \alpha}=\frac{80 \cdot\left(\rho_{12}-0,12\right)^{1,11}}{1,07 \cdot\left(\rho_{12}-0,12\right)^{-0,07} \cdot \operatorname{sen}^{2} \alpha+\cos ^{2} \alpha}(\mathrm{MPa})
$$

Where: $\rho_{12}=$ density at $12 \%$ moisture content, in $\mathrm{g} / \mathrm{cm}^{3} ; \alpha=$ loading angle relative to the grain of the outer layers, in degrees.

\subsection{Dong et al. approach}

Recently DONG et al. [14, 32, 33] also investigated the embedment behavior of dowel-type fasteners positioned perpendicular to CLT panel. Experimental tests were carried out in accordance to ASTM D5764-97a [35] half-hole test method, using smooth dowels with diameters of $10 \mathrm{~mm}, 12 \mathrm{~mm}$ and $14 \mathrm{~mm}$, loaded $0^{\circ}, 45^{\circ}$ and $90^{\circ}$ to the grain of outer layers. CLT panels manufactured with three different wood species were tested, with mean density between $430 \mathrm{~kg} / \mathrm{m}^{3}$ and $570 \mathrm{~kg} / \mathrm{m}^{3}$, and average moisture contents between 11 and $12 \%$. All the CLT specimens had three layers and $60 \mathrm{~mm}$ of total thickness, but different build-up ratios were considered.

From approximate 660 results, the authors developed an equation (Eq. 4) for the embedment strength derived by a nonlinear regression analysis. According to DONG et al. [32], the thickness ratio of transverse 
layer statistically influences the embedment strength and cannot be neglected.

$$
\mathrm{f}_{\mathrm{h}, \text { avg } \alpha}=0,33640,4551-0,0205 \mathrm{~d} \rho_{12} \frac{\mathrm{tt}}{1,4101 \cos ^{2} \alpha+\sin ^{2} \alpha}+\frac{1-\mathrm{tt}}{\left.1,4101 \sin ^{2} \alpha+\cos ^{2} \alpha\right)}(\mathrm{MPa})
$$

Where: $\mathrm{d}=$ dowel diameter, in $\mathrm{mm} ; \rho_{12}$ density at $12 \%$ moisture content, in $\mathrm{kg} / \mathrm{m}^{3} ; \mathrm{tt}=$ thickness ratio of CLT layers loaded perpendicular to the grain; $\alpha=$ loading angle relative to the grain of the outer layers, in degrees.

\section{MATERIALS AND METHODS}

In this section, the materials, specimen configurations and methods used in the experimental program are presented.

\subsection{Materials}

Pinus Taeda wood from the same plot of the forest planted in southern Paraná State (Brazil) was used to produce CLT and solid timber specimens. Density and moisture content tests, compression parallel to the grain $\left(f_{c, 0}\right)$ and compression perpendicular to the grain $\left(f_{c, 90}\right)$ were performed to characterize the sawn wood, according to the methods proposed in the Brazilian standard NBR 7190 [36]. The number of specimens, the mean values and the coefficient of variation are shown in Table 2 .

Table 2: Physical and mechanical properties of timber.

\begin{tabular}{clcc}
\hline $\begin{array}{l}\text { NUMBER OF } \\
\text { SPECIMENS }\end{array}$ & \multicolumn{1}{c}{ PROPERTY } & MEAN VALUES & CV (\%) \\
\hline 47 & Moisture content & $12.99 \%$ & 3.6 \\
47 & Density $(\rho)$ & $443.62 \mathrm{~kg} / \mathrm{m}^{3}$ & 15.5 \\
13 & Compression strength parallel to the grain $\left(\mathrm{f}_{\mathrm{c}, 0}\right)$ & $26.62 \mathrm{MPa}$ & 15.8 \\
10 & Compression strength perpendicular to the grain $\left(\mathrm{f}_{\mathrm{c}, 90}\right)$ & $3.25 \mathrm{MPa}$ & 9.1 \\
\hline
\end{tabular}

Fully-threaded dowel-type fasteners were used in the tests, with diameters of 6, 8, 10, 12 and $16 \mathrm{~mm}$. According to the manufacturer, the dowels are made of low carbon steel, specified as ISO 898 Class 5.8.

\subsection{Specimens}

The CLT panels tested were made with three layers of $20 \mathrm{~mm}$ thick lamellae, bonded orthogonally to each other. The build-up (20-20-20 mm) for the CLT specimen was chosen because it is the smallest thickness sold by different manufacturers. The lamellae were bonded with a one-component polyurethane adhesive applied at a rate of $200 \mathrm{~g} / \mathrm{m}^{2}$. This adhesive was chosen because it is used by different industries producing CLT and in research such as GSELL et al. [6], PEREIRA and CALIL JUNIOR [37] and OTTENHAUS et al. [38]. The specimens were submitted to a compression pressing equal to $0.8 \mathrm{MPa}$, for 4 hours, under a temperature between 20 and $25^{\circ} \mathrm{C}$.

The sizes of the CLT and solid timber specimens were determined independently of the dowel diameter and the angle between the load and the grain direction. All specimens had a total thickness (A) of $60 \mathrm{~mm}$, length (B) and height (C) of $100 \mathrm{~mm}$, as shown in Figure 1. All specimens were made with sections of lamellae without any defects, and the CLT without gaps between the lamellae. 


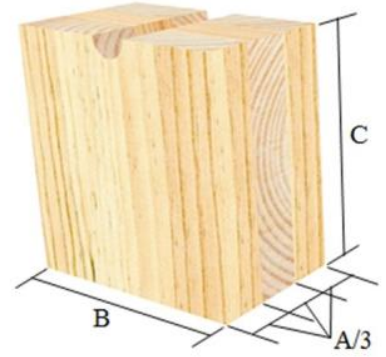

(a)

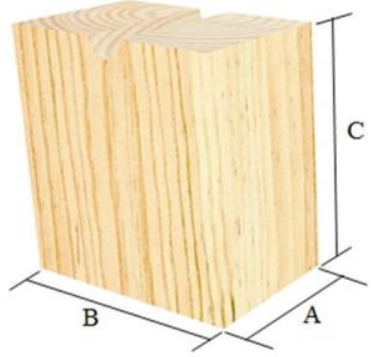

(c)

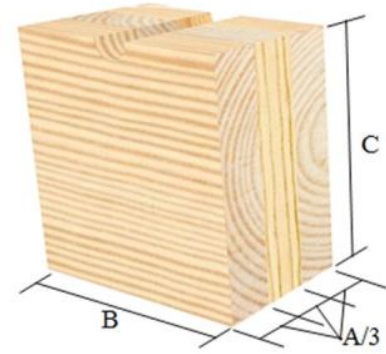

(b)

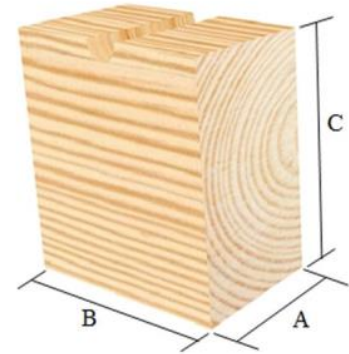

(d)

Figure 1: Specimens sizes: (a) CLT - load parallel to the grain (direction 1); (b) CLT - load perpendicular to the grain (direction 2); (c) solid timber - direction 1; (d) solid timber - direction 2.

In order to evaluate the two loading orientations and the five dowel diameters, the specimens were replicated six times, resulting in a total of 60 CLT specimens and 60 solid timber specimens. After all the specimens were made, they were conditioned at a temperature of $20 \pm 2^{\circ} \mathrm{C}$ and $65 \pm 5 \%$ relative humidity of the environment before the tests, until reaching a constant mass.

\subsection{Embedding tests}

All embedding tests were done on EMIC (DL30000) universal testing machine, according to ASTM D576497a: 2018 [35] half-hole test method, as shown in Figure 2. The dowels were inserted into the half-holes of the specimens and loaded under $0^{\circ}$ and $90^{\circ}$ to the grain direction, which will be hereinafter referred to as direction 1 and 2, respectively, for simplification purposes. For CLT, the inclination between the load and the grains was considered regarding to the outer layer of the panel.

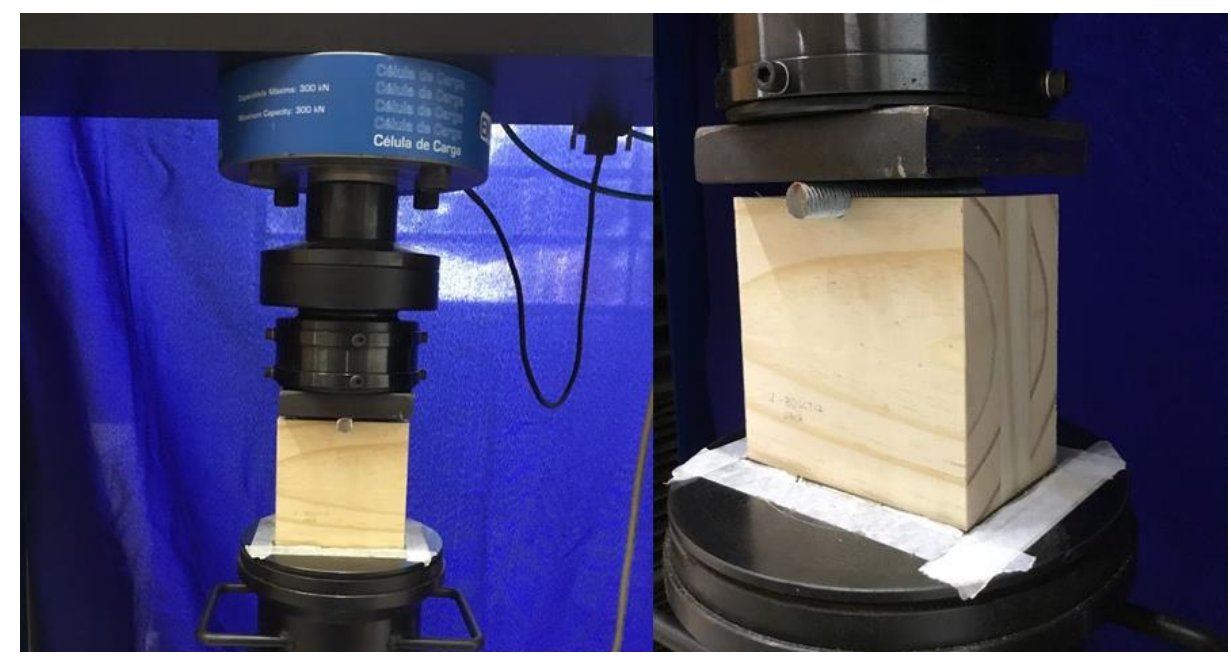

Figure 2: Experimental setup.

The loading rate was adjusted so the failure occurred between 4 and 7 minutes, based on preliminary tests. The test was stopped whenever one of the two following conditions happened: the achievement of the maximum load of the machine; the displacement of the fastener in half the size of its diameter. The embed- 
ding strength was determined using the 5\% off-set method, which consists of drawing a line parallel to the first linear section of the load-displacement curve, moved 5\% from the diameter of dowel, as shown in Figure 3. The intersection between this line and the curve defines the embedding force $\left(\mathrm{F}_{\mathrm{e}, 5 \% \mathrm{~d}}\right)$. Therefore, the embedding strength $\left(\mathrm{f}_{\mathrm{e}}\right)$ is calculated according to Eq. 5 .

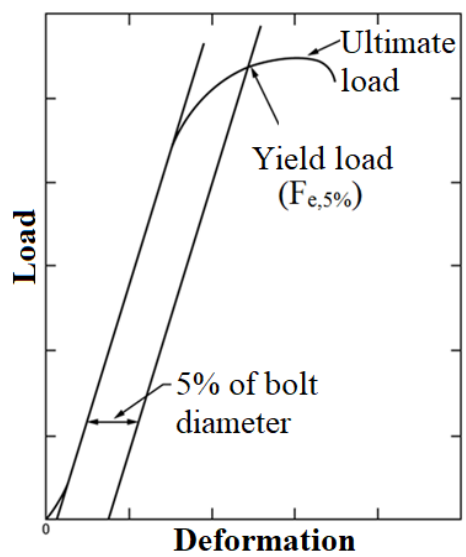

Figure 3: Embedding force according to 5\% off-set test method. Source: Adapted from ASTM D5764-97a: 2018 [35]

\section{RESULTS AND DISCUSSION}

The following nomenclature was adopted to show the results for the embedding strength: $\mathrm{f}_{\mathrm{e}, 0, \mathrm{CLT}}$ and $\mathrm{f}_{\mathrm{e}, 90, \mathrm{CLT}}$ corresponds to the CLT embedding strength in direction 1 and 2, respectively; $f_{e, 0, s t}$ and $f_{e, 90, s t}$ corresponds to the solid timber embedding strength in direction 1 and 2, respectively. Table 3 shows the average values of the embedding strength for CLT and solid timber, in direction 1 and 2, and their respective coefficients of variation $(\mathrm{CV})$, obtained for each dowel diameter.

Table 3: Results of the embedding tests.

\begin{tabular}{|c|c|c|c|c|c|c|c|c|}
\hline \multirow{2}{*}{$\begin{array}{l}\text { DIAMETER } \\
(\mathrm{mm})\end{array}$} & \multicolumn{4}{|c|}{ CLT } & \multicolumn{4}{|c|}{ SOLID TIMBER } \\
\hline & $\begin{array}{l}f_{e, 0,0, t^{*}} \\
(\mathrm{MPa})\end{array}$ & $\begin{array}{l}\text { CV } \\
(\%)\end{array}$ & $\begin{array}{l}\mathrm{f}_{\mathrm{e}, 90, \mathrm{clt}}{ }^{*} \\
(\mathrm{MPa})\end{array}$ & $\begin{array}{l}\text { CV } \\
(\%)\end{array}$ & $\begin{array}{c}f_{e, 0, s t}{ }^{*} \\
(\mathrm{MPa})\end{array}$ & $\begin{array}{l}\text { CV } \\
(\%)\end{array}$ & $\begin{array}{l}f_{\mathrm{e}, 90, \mathrm{st}^{*}} \\
(\mathrm{MPa})\end{array}$ & $\begin{array}{l}\text { CV } \\
(\%)\end{array}$ \\
\hline 6 & 24.23 & 18.49 & 20.05 & 9.20 & 22.11 & 18.60 & 16.29 & 25.37 \\
\hline 8 & 22.32 & 16.61 & 20.42 & 16.60 & 22.97 & 12.88 & 16.65 & 27.68 \\
\hline 10 & 22.18 & 8.18 & 18.83 & 17.42 & 24.23 & 8.77 & 15.95 & 27.62 \\
\hline 12 & 22.26 & 11.64 & 16.86 & 5.95 & 23.00 & 10.72 & 15.31 & 26.68 \\
\hline 16 & 22.04 & 12.12 & 19.32 & 11.82 & 23.31 & 7.73 & 15.28 & 23.89 \\
\hline
\end{tabular}

\subsection{Effect of dowel diameter}

All results were shown on scatter graphs and trend lines were plotted to analyze the influence of dowel diameter on the embedding strength. Figure 4 shows the relationship between the CLT embedding strength and dowel diameters, in direction 1 (Figure $4 \mathrm{a}$ ) and direction 2 (Figure 4b). When analyzing the trend lines, a decrease in the embedding strength was observed as the dowel diameter increases in both directions. The same pattern was observed by DONG et al. [14, 32]. 


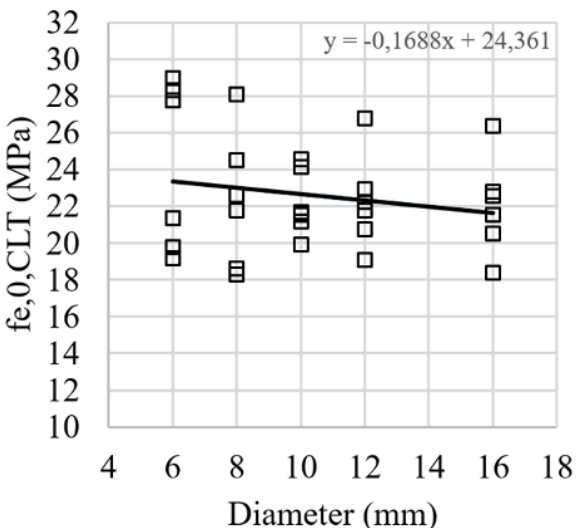

(a)

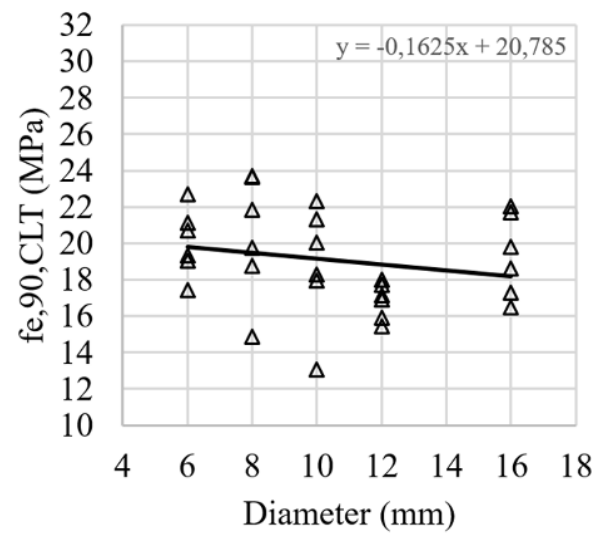

(b)

Figure 4: Relation between the embedding strength and dowel diameter for CLT: (a) direction 1 and (b) direction 2.

Figure 5 shows the relations between the solid timber embedding strength and the dowel diameter, in direction 1 (Figure 5a) and direction 2 (Figure 5b). Through the trend line, there is no strength decreasing as diameter increases in direction 1, corroborating the results found by SANDHAAS et al. [20], SAWATA and YASUMURA [26] and WILKINSON [25], which showed that the embedding strength shows a weak influence by dowel diameters in this direction.

On the other hand, considering the loading in direction 2, there is a tendency to decrease the embedding strength as dowel diameters increases, corroborating the results observed by EHLBECK and WERNER [23], SAWATA and YASUMURA [26] and SCHOENMAKERS, JORISSEN and LEIJTEN [39].

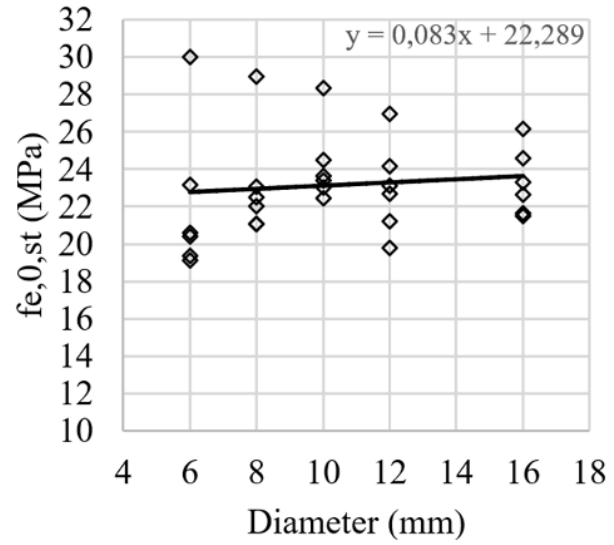

(a)

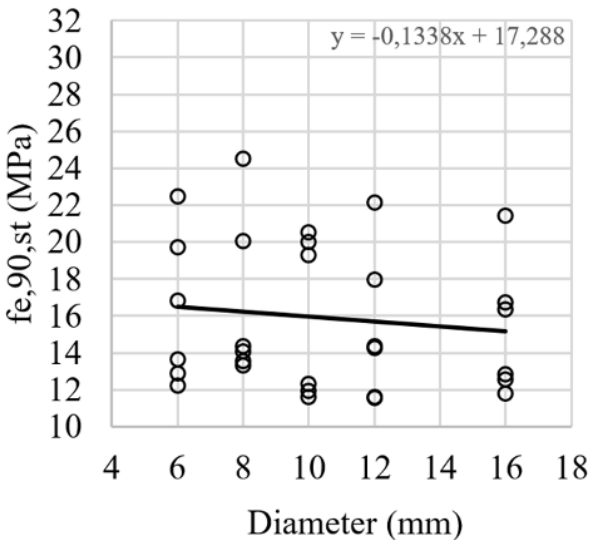

(b)

Figure 5: Relation between embedding strength and dowel diameter for solid timber: (a) direction 1and (b) direction.

Results showing the same pattern with increasing in diameters $\left(\mathrm{f}_{\mathrm{e}, 0, \mathrm{CLT}}, \mathrm{f}_{\mathrm{e}, 90, \mathrm{CLT}}\right.$ and $\left.\mathrm{f}_{\mathrm{e}, 90, \mathrm{st}}\right)$, are illustrated in Figure 6. The trend lines highline that the magnitude of the tendency of decrease in the embedding strength is similar for the three series. For CLT, the influence of the diameters does not depend on the loading direction $\left(0^{\circ}\right.$ or $90^{\circ}$ in this research), unlike the solid timber in which the influence of the diameters is related to the inclination between loading and grain direction. 


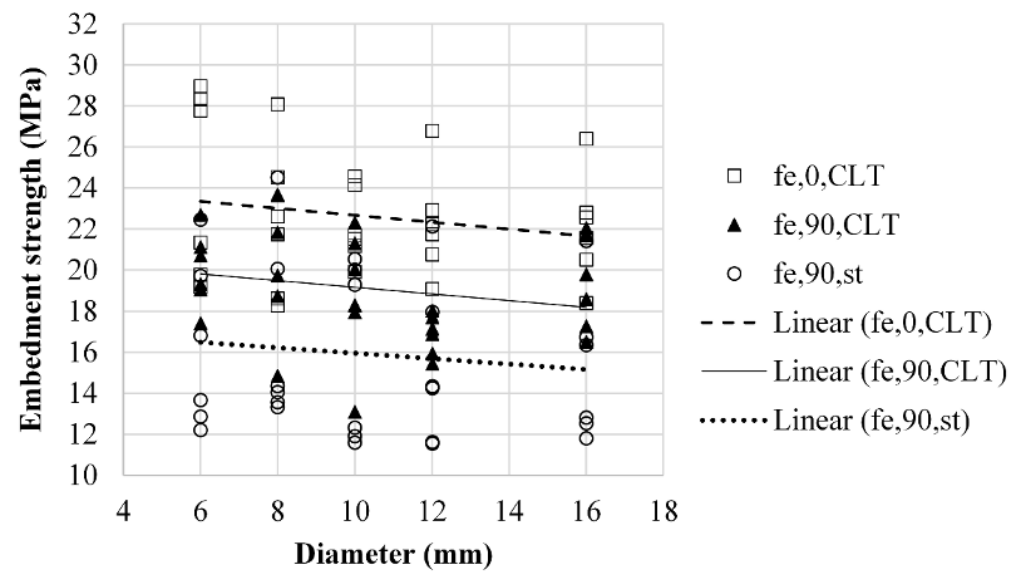

Figure 6: Relations between the embedding strength and dowel diameters.

\subsection{Effect of loading direction}

The ratios between the mean values of the embedding strength in direction 1 and 2, for CLT and solid timber, are shown graphically in Figure 7.

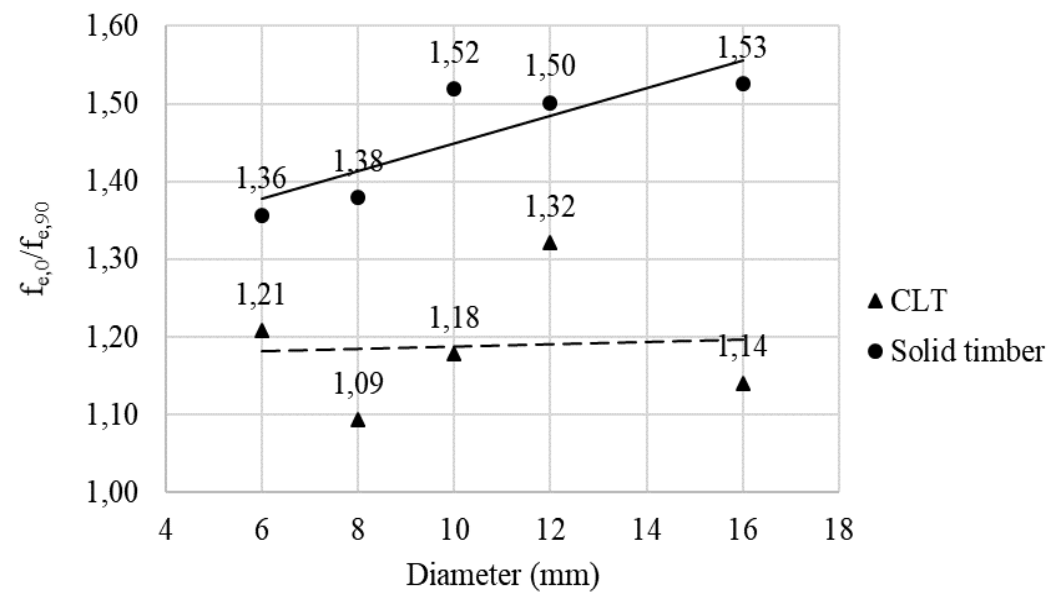

Figure 7: Embedding strength in direction 1/direction 2 ratio for CLT and solid timber for each dowel diameter.

For all diameters analyzed, the ratio $\mathrm{f}_{\mathrm{e}, 0} / \mathrm{f}_{\mathrm{e}, 90}$ had values greater than 1 , showing that the embedding strength in direction 1 was higher than that in direction 2, for both CLT and solid timber. Such observation is similar to the results obtained by SANTOS et al. [40], SAWATA and YASUMURA [26] and WILKINSON [25].

When analyzing the trend lines of Figure 7, the ratio for CLT is little influenced by the dowel diameter. For solid timber, the ratio increases as the dowel diameter increases. On the other hand, the CLT homogenization is evidenced by the lower ratio between $\mathrm{f}_{\mathrm{e}, 0} / \mathrm{f}_{\mathrm{e}, 90}$ when compared to the solid timber, indicating that the influence of loading direction is minimized by the effect of cross lamination. However, the curves obtained in the tests with the other diameters have similar development.

Figure 8 shows typical curves for the $8 \mathrm{~mm}$ dowel tests; however, the curves obtained in the tests with the other diameters studied have similar development. The similarity of CLT behavior when subjected to loading in direction 1 and 2 can be observed in the curves of Figure 8a. For both load directions in the CLT tests, the diagram shows an initial linear stretch and the embedding stress continues to increase as the displacement increases, even after the proportionality limit.

As shown in Figure 8b, the curve for solid timber loaded in direction 1 has a plastic behavior characteristic, with a significant increase in displacement without a large increase in the embedding stresses, after reaching the proportionality limit. In direction 2, the curve for solid timber practically has an elastic behavior characteristic. 
CLT

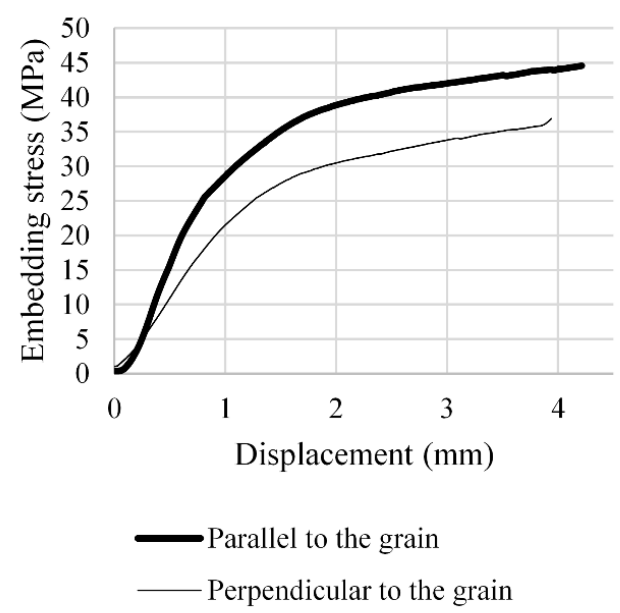

(a)

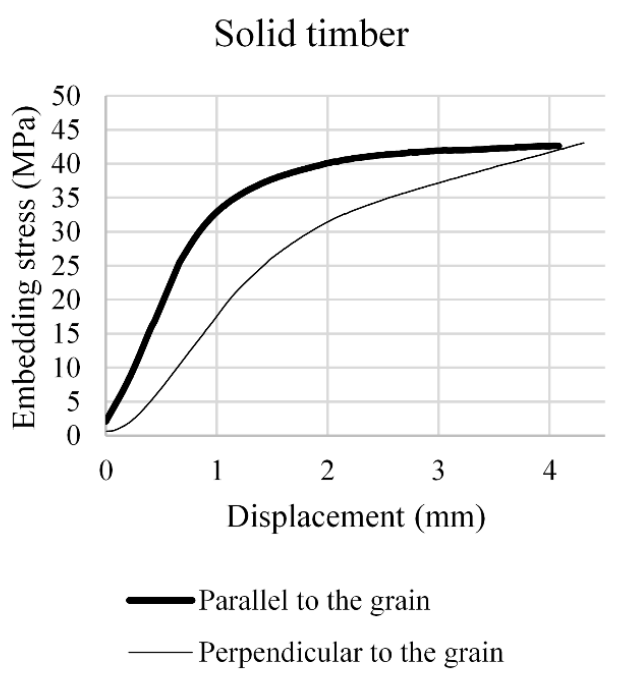

(b)

Figure 8: Typical embedding stress-displacement curves to loads in direction 1 and 2 for (a) CLT and (b) solid timber.

\subsection{Comparison between the embedding strength in CLT and solid timber}

The mean results of embedding strength for CLT and solid timber are shown graphically in Figure 9. For loads in direction 1 (Figure 9a), except for the $6 \mathrm{~mm}$ diameter, the average embedding strength of the CLT was lower than the solid timber. This is due to the presence of a layer loaded perpendicular to the grain direction, which decreases the strength when compared to the solid timber. For $8 \mathrm{~mm}$ dowel diameter, for example, the CLT embedding strength in direction 1 was $8 \%$ lower than in solid timber. For loads in direction 2 , the mean embedding strength for CLT was higher than in solid timber, which confirms that the presence of layers loaded in the direction parallel to the grain increases the strength when compared to solid timber. The CLT embedding strength in direction 2 increased $26 \%$ for the $16 \mathrm{~mm}$ dowel diameter, for example.

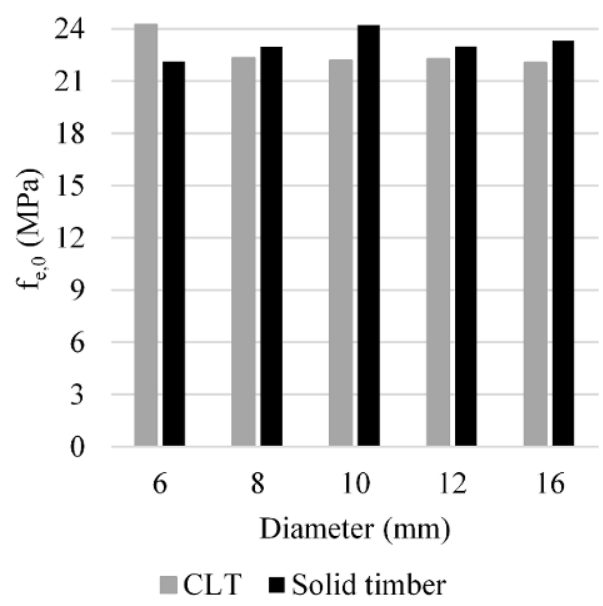

(a)

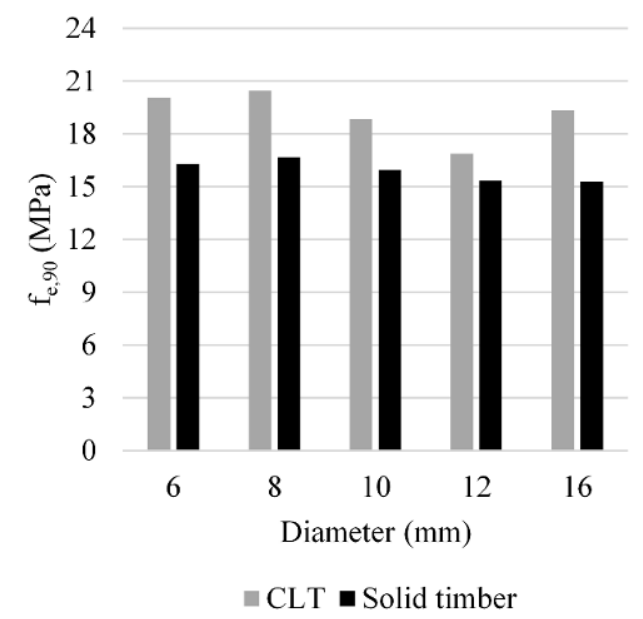

(b)

Figure 9: Embedding strength mean values for CLT and solid timber for loads (a) in direction 1 and (b) direction 2.

A one-way analysis of variance (one-way ANOVA) was performed to verify if the differences between the mean results of the embedding strength for CLT and solid timber were significant. ANOVA was applied separately for each dowel diameter and load direction; the material (CLT and solid timber) was the only difference among the groups. The statistical test was applied ten times, considering a significance level $\alpha=0.05$. Whenever ANOVA was applied, the degree of freedom among groups was 1 and the degree of freedom within groups was 10 , obtaining from the distribution table F-Snedecor $F_{0,05 ; 1 ; 10}=4.96$. Table 4 
summarizes the ANOVA results, showing the critical F-value and P-value results for each combination of dowel diameter and loading direction.

Table 4: Summary of ANOVA results for the comparison between CLT and solid timber.

\begin{tabular}{cccccc}
\hline \multirow{2}{*}{$\begin{array}{c}\text { DIAMETER } \\
(\mathbf{m m})\end{array}$} & \multicolumn{2}{c}{ PARALLEL TO THE GRAIN } & & \multicolumn{2}{c}{ PERPENDICULAR THE TO GRAIN } \\
\cline { 2 - 3 } \cline { 5 - 5 } & F $_{\text {CRITICAL }}$ & P-VALUE & & F $_{\text {CRITICAL }}$ & P-VALUE \\
\hline 8 & 0.784 & 0.397 & & 4.149 & 0.069 \\
10 & 0.168 & 0.691 & & 2.607 & 0.138 \\
12 & 3.254 & 0.101 & & 1.651 & 0.228 \\
16 & 0.254 & 0.625 & & 0.808 & 0.390 \\
\hline
\end{tabular}

The ANOVA results reveal that only for direction 2 and diameter of $16 \mathrm{~mm}$, the mean values of embedding strength for CLT and solid timber were statistically different ( $\mathrm{P}$-valor $\left\langle\alpha\right.$ e $\left.\mathrm{F}_{\text {critical }}>\mathrm{F}_{0.05 ; 1 ; 10}\right)$. For the other cases, there are no statistical indications that the mean values for CLT and solid timber are different (Pvalor $>\alpha$ e $\left.\mathrm{F}_{\text {critic }}<\mathrm{F}_{0.05 ; 1 ; 10}\right)$.

\subsection{Comparison between the experimental and analytical results}

In this section, the mean embedding strengths of CLT are compared with those calculated according to the equations presented in Section 2. Table 5 shows the density value used in each equation and the percentage difference between the experimental and analytical results for direction 1 . The comparison between the experimental values and the empirical equations shows that BLASS and UIBEL [28] approach overestimated the CLT embedment strength in direction 1 for all considered diameters. The difference between model 1 and model 2 from BLASS, and UIBEL [28] and test results were up to $62.4 \%$ and $65.7 \%$, respectively.

Results calculated according to the equation proposed by KENNEDY et al. [31] show significant agreement with the embedding strength in direction 1, being the biggest difference observed for diameter of 6 $\mathrm{mm}$, when the calculated value was $7.0 \%$ lower than the mean value of the test.

Table 5: Embedding strength values in direction 1 compared with analytical results.

\begin{tabular}{|c|c|c|c|c|c|c|c|c|}
\hline \multirow{2}{*}{$\begin{array}{l}\text { DIAMETER } \\
(\mathrm{mm})\end{array}$} & \multirow{2}{*}{$\begin{array}{c}\text { TEST } \\
\mathrm{f}_{\mathrm{e}, 0, \mathrm{CLT} \text {,mean }} \\
(\mathrm{MPa})\end{array}$} & \multicolumn{3}{|c|}{ BLASS AND UIBEL } & \multicolumn{2}{|c|}{ KENNEDY ET AL. } & \multicolumn{2}{|c|}{ DONG ET AL. } \\
\hline & & $\begin{array}{l}\rho_{\mathrm{ap}, \text { mean }} \\
\left(\mathrm{kg} / \mathbf{m}^{3}\right)\end{array}$ & $\begin{array}{c}\text { MODEL } 1 \\
\text { EQ. (1) }\end{array}$ & $\begin{array}{l}\text { MODEL } 2 \\
\text { EQ. (2) }\end{array}$ & $\begin{array}{c}\rho_{12 \text {,mean }} \\
\left(\mathrm{g} / \mathrm{cm}^{3}\right)^{\star}\end{array}$ & EQ. (3) & $\begin{array}{c}\rho_{12, \text { mean }} \\
\left(\mathrm{kg} / \mathrm{m}^{3}\right)^{\star}\end{array}$ & EQ. (4) \\
\hline 6 & 24.23 & 443.62 & $+54.6 \%$ & $+57.9 \%$ & 0.439 & $-7.0 \%$ & 439.33 & $+82.19 \%$ \\
\hline 8 & 22.32 & 443.62 & $+62.4 \%$ & $+65.7 \%$ & 0.439 & $+1.0 \%$ & 439.33 & $+73.32 \%$ \\
\hline 10 & 22.18 & 443.62 & $+57.8 \%$ & $+61.1 \%$ & 0.439 & $+1.6 \%$ & 439.33 & $+49.77 \%$ \\
\hline 12 & 22.26 & 443.62 & $+51.6 \%$ & $+54.8 \%$ & 0.439 & $+1.2 \%$ & 439.33 & $+24.63 \%$ \\
\hline 16 & 22.04 & 443.62 & $+42.0 \%$ & $+44.9 \%$ & 0.439 & $+2.2 \%$ & 439.33 & $-23.72 \%$ \\
\hline
\end{tabular}

* $\rho_{12, \text { mean }}$ calculated by Kollmann's method

Figure that the equation proposed by DONG et al. [32] considers a decrease of embedding strength as the dowel diameter increases, however this is greater than decrease observed in the tests and that from BLASS and UIBEL [28] method. The embedding strength in direction 1 calculated according to DONG et al. [32], showed in Table 5, was conservative only for diameter of $16 \mathrm{~mm}$. For the other diameters considered in this research, the Equation 4 resulted in values up to $82.19 \%$ higher than those from tests. 


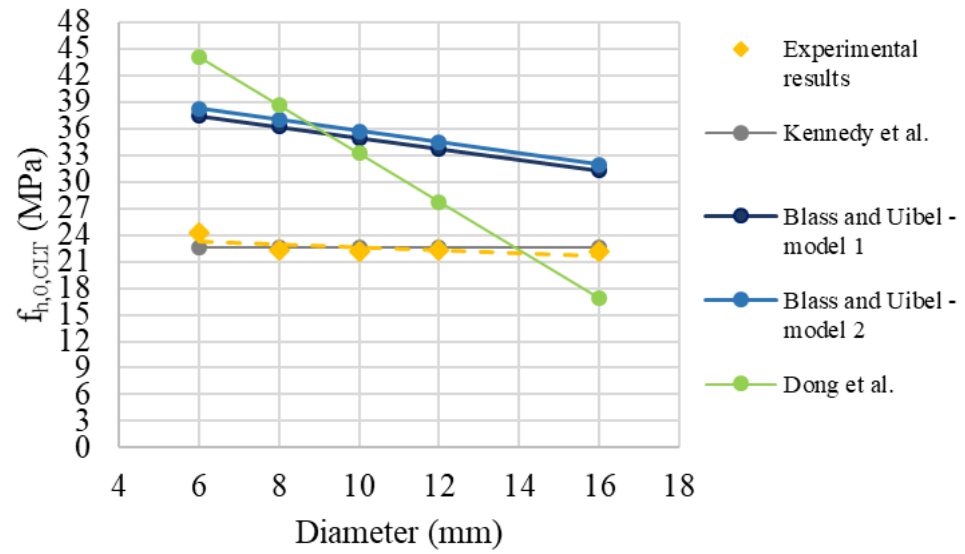

Figure 10: Comparison between mean values and analytical results for direction 1.

Table 6 shows the density value used in each equation and the percentage difference between the experimental and analytical results for direction 2. As well as for loads in direction 1, model 1 and model 2 proposed by BLASS and UIBEL [28] overestimated the CLT embedding strength in direction 2 for all considered diameters, as shown in Figure 11. In this case, the differences between model 1 and model 2 and test results were up to $82.1 \%$ and $72.5 \%$, respectively. Comparing the mean strength in direction 2 with those calculated from equation proposed by KENNEDY et al. [31], a good agreement could be seen. The embedding strength in direction 2, calculated using the equation proposed by DONG et al. [32], was up to $96.51 \%$ higher than the experimental values.

Table 6: Embedding strength values in direction 2 compared with analytical results.

\begin{tabular}{|c|c|c|c|c|c|c|c|c|}
\hline \multirow{2}{*}{$\begin{array}{l}\text { DIAMETER } \\
\quad(\mathrm{MM})\end{array}$} & \multirow{2}{*}{$\begin{array}{c}\text { TEST } \\
\mathbf{f}_{\mathrm{e}, 90, \mathrm{CLT} \text {,mean }} \\
(\mathrm{MPa})\end{array}$} & \multicolumn{3}{|c|}{ BLASS and UIBEL } & \multicolumn{2}{|c|}{ KENNEDY et al. } & \multicolumn{2}{|c|}{ DONG et al. } \\
\hline & & $\begin{array}{l}\rho_{\mathrm{ap}, \text { mean }} \\
\left(\mathrm{kg} / \mathbf{m}^{3}\right)\end{array}$ & $\begin{array}{c}\text { MODEL } 1 \\
\text { EQ. [1] }\end{array}$ & $\begin{array}{c}\text { MODEL } 2 \\
\text { EQ. [2] }\end{array}$ & $\begin{array}{c}\rho_{12, \text { mean }} \\
\left(\mathbf{g} / \mathbf{c m}^{3}\right)^{\star}\end{array}$ & EQ. [3] & $\begin{array}{c}\rho_{12, \text { mean }} \\
\left(\mathrm{kg} / \mathrm{m}^{3}\right)^{\star}\end{array}$ & EQ. [4] \\
\hline 6 & 20.05 & 443.62 & $+69.8 \%$ & $+63.5 \%$ & 0.439 & $-3.1 \%$ & 439.33 & $+96.51 \%$ \\
\hline 8 & 20.42 & 443.62 & $+61.3 \%$ & $+55.3 \%$ & 0.439 & $-4.8 \%$ & 439.33 & $+69.09 \%$ \\
\hline 10 & 18.83 & 443.62 & $+69.0 \%$ & $+62.6 \%$ & 0.439 & $+3.2 \%$ & 439.33 & $+57.46 \%$ \\
\hline 12 & 16.86 & 443.62 & $+82.1 \%$ & $+75.2 \%$ & 0.439 & $+15.3 \%$ & 439.33 & $+46.92 \%$ \\
\hline 16 & 19.32 & 443.62 & $+47.2 \%$ & $+41.7 \%$ & 0.439 & $+0.6 \%$ & 439.33 & $-22.31 \%$ \\
\hline
\end{tabular}

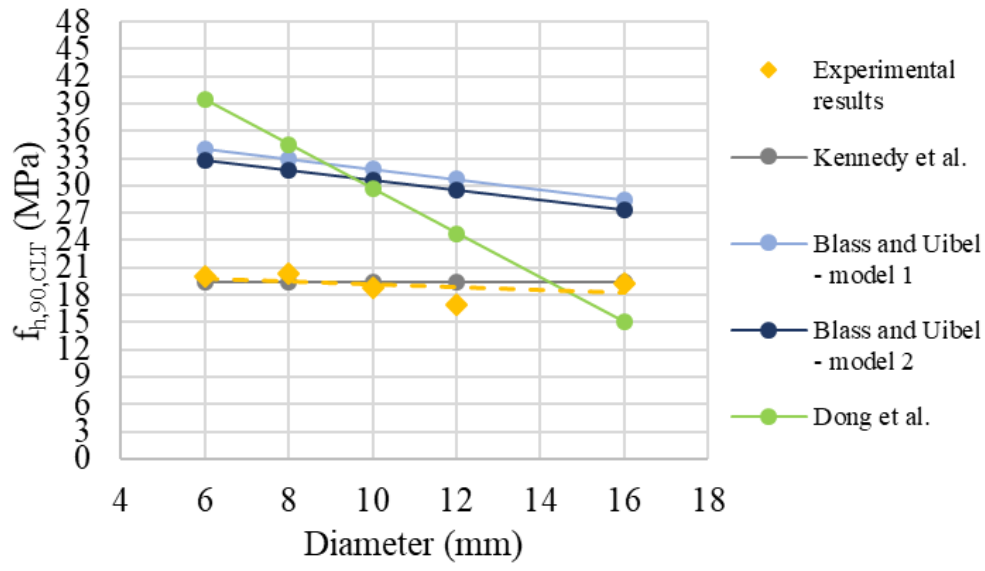

Figure 11: Comparison between mean values and analytical results for direction 2. 
Although the equations proposed by BLASS and UIBEL [28] were the most evaluated in scientific works involving steel connectors, the embedding strengths calculated by Equations [1] and [2] resulted in higher values than those obtained in tests carried out in this study, for both directions of loads, even considering the limitations suggested by BLASS and UIBEL [28] (i.e., CLT layers thinner than $40 \mathrm{~mm}$ and a build-up ratio $\sum \mathrm{t}_{0, \mathrm{i}} / \sum \mathrm{t}_{90 . \mathrm{j}}$ between 0.95 and 2.1). The same was observed and reported by TUHKANEN, MÖLDER and SCHICKHOFER [41] and OTTENHAUS et al. [42].

One reason that could be pointed out for the difference between the experimental results and those calculated from BLASS and UIBEL [28] equations is the test method, since this research was carried out according to ASTM D5764-97a:2018 [35], whereas the research accomplished by BLASS and UIBEL [28] was carried out according to BS EN 383:2007 [43]. TUHKANEN, MÖLDER and SCHICKHOFER [41] also performed tests according to BS EN 383: 2007 [43], and even so they observed the equations for models 1 and 2 overestimate the embedding strength.

Other parameter that could be indicated as cause for this difference is the roughness of the dowel. SJÖDIN, SERRANO and ENQUIST [44] studied the influence of roughness of the dowel on the embedding strength, and they concluded that the distribution of deformations around the dowel is influenced by the surface roughness. Their tests with threaded dowels resulted in a load capacity approximately $44 \%$ greater than tests with smooth dowels. However, this hypothesis can be discarded because TUHKANEN, MÖLDER and SCHICKHOFER [41] and OTTENHAUS et al. [42] used smooth dowels in their research and even so they did not found a good agreement between BLASS and UIBEL equations and the experimental results.

Although BLASS and UIBEL [28] limited the equations for CLT with layers up to $40 \mathrm{~mm}$, only one group of their tests considered CLT with this thickness. As summarized in Table 1, the authors carried out tests mostly in panels manufactured with layers thinner than $20 \mathrm{~mm}$. It is also noted that for the same dowel diameter, the results for CLT with thinner layers were higher than the results for CLT with thicker layers. As performed in this research, TUHKANEN, MÖLDER and SCHICKHOFER [41] and OTTENHAUS et al. [42] also used CLT with layers equal or higher than $20 \mathrm{~mm}$. Therefore, it is understood that the models 1 and 2 proposed by BLASS and UIBEL [28] can overestimate the embedding strength, possibly because the equations were based on experimental results obtained predominantly in CLT specimens with layers whose thickness was less than $20 \mathrm{~mm}$. TUHKANEN, MÖLDER and SCHICKHOFER [41] corroborate this statement.

The percentage differences between the experimental results and those calculated according to the equation proposed by KENNEDY et al. [31] are relatively small when compared with those calculated from equations suggested by the other authors, resulting in the best fit with the experimental results.

Comparing the parameters included in the proposed empirical models $[28,31,32]$ to determine the embedding strength in CLT, there are controversies regarding the influence of the dowel diameter. By analyzing the influence of the dowel diameter (yellow dashed line in Figures 10 and 11), it can be noted from the trend line that the decrease in the experimental embedding strength, with the increase in the dowel diameter, is less than that obtained by the equations.

\subsection{Failure modes}

Tests performed showed the failure modes were similar in the solid timber and CLT specimens. In CLT, the failure occurred individually in each layer. The same was observed by NAKASHIMA et al. [45] in CLT tests with five layers.

Three failure modes were observed in direction 1 on solid timber, arbitrarily named mode 1 , mode 2 and mode 3 (Figure 12a, b, c). The failure modes observed for solid timber in direction 2 were randomly named mode 4, mode 5 and mode 6 (Figure 12d, e, f). 


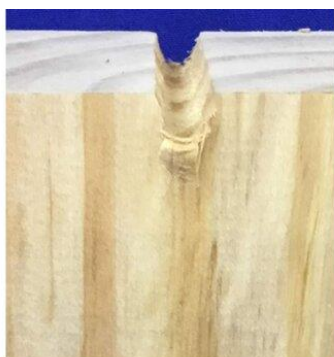

(a)

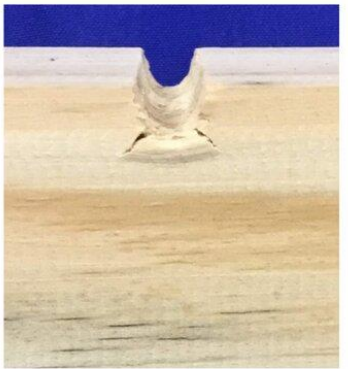

(d)

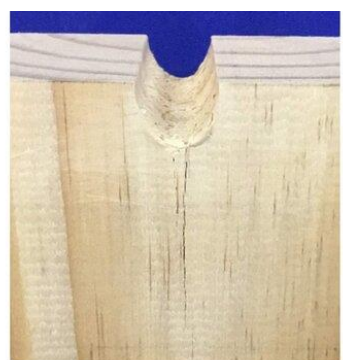

(b)

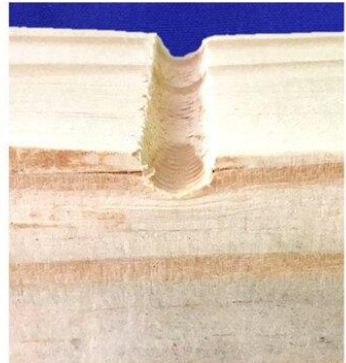

(e)

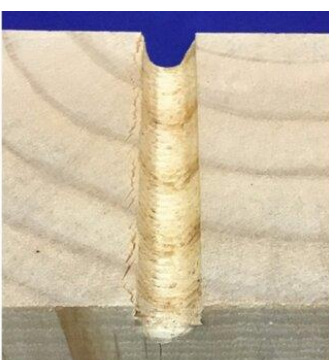

(c)

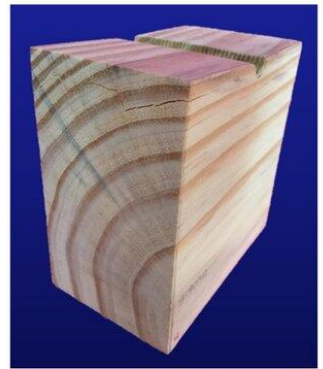

(f)

Figure 2: Failure modes on solid timber loaded in direction 1 (a) mode 1, (b) mode 2, (c) mode 3; loaded in direction 2: (d) mode 4 , (e) mode 5, (f) mode 6 .

Mode 1 (Figure 12a) corresponds to the localized crushing of wood fibers in the region just below the dowel. In mode 2 (Figure 12b), there was wood cracking below the dowel and fiber crushing. This cracking was related to higher displacement values during the test and is considered a final state of deformation after crushing. Failure modes 1 and 2 have also been reported by RAMMER [46]. Mode 3 (Figure 12c) corresponds to the cracks at the top of the specimen, associated to ruptures of mode 1 or mode 2 . Possibly mode 3 is related to the half-hole model of the specimens, where the non-continuity of the material allows this kind of break. The most frequently observed failure modes in solid timber embedding tests in direction 1 were: mode 1 and mode 3 associated to mode 1 .

Failure mode 4 (Figure 12d) is characterized by localized crushing and wood fibers breaking in the region below the dowel, arising from inclined cracks at an angle of about 45 degrees. In mode 5 (Figure 12e), the wood fibers were cracked in the vicinity of the hole and crushed in the region below the dowel. In failure modes 4 and 5, at the initial loading stage, the wood fibers were crushed and the cracks appeared in a final rupture stage. RAMMER [46] reported in his research the failure mode related only to the early stage of deformation. In failure mode 6 , cracks on one or both sides of the specimen were observed, as found in the study of RAMMER [46]. Modes 4 and 5 were more frequently observed in tests with smaller diameters (6 $\mathrm{mm}, 8 \mathrm{~mm}$ and $10 \mathrm{~mm}$ ), while mode 6 was observed more frequently in tests with diameters of $12 \mathrm{~mm}$ and $16 \mathrm{~mm}$.

Figure 13 shows failure modes of CLT specimens loaded in direction 1 (Figure 13a) and direction 2 (Figure 13b). The same failure modes reported for solid timber in direction 1 (mode 1, mode 2 and mode 3 ) were found in CLT when loaded in direction 1. The wood cracking below the dowel and fiber crushing was also observed by DONG et al. [33]. Ruptures in the central layer were not visualized in any of the CLT specimens loaded in direction 1 . The same failure modes reported in solid timber in direction 2 (mode 4 , mode 5 and mode 6) were observed in CLT when loaded in direction 2. Cracks in the top of the central layer (loaded parallel to the grain) were observed in some specimens, corresponding to failure mode 3 . 

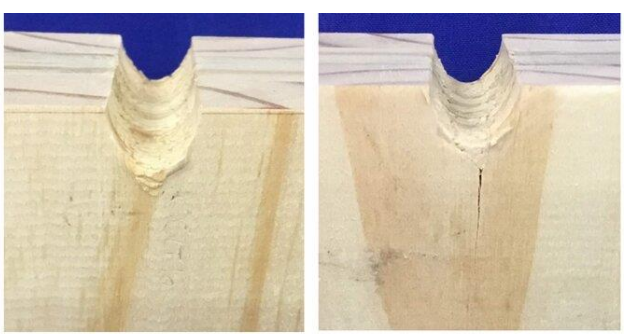

(a)
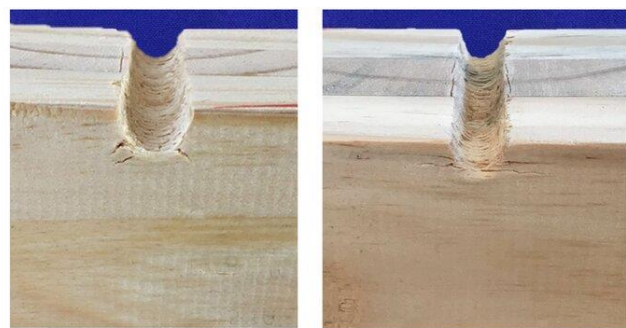

(b)
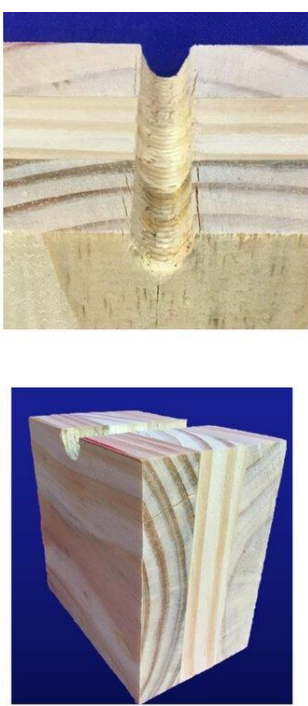

\section{CONCLUSION}

This research experimentally investigated the behavior of CLT specimens submitted to dowel embedment. Half-hole embedment tests were carried out on solid timber and CLT specimens, which were composed by three layers of pine lamellae with the same thickness $(20-20-20 \mathrm{~mm})$, bonded with one-component polyurethane adhesive. The loads were applied in parallel (direction 1) and perpendicular (direction 2) to the grain directions, considering five dowel diameters $(6,8,10,12$ and $16 \mathrm{~mm})$. A total of 120 specimens were tested.

By comparing the experimental results obtained, the following conclusions can be highlighted:

- Through the analysis of the trend lines, the CLT loaded in directions 1 and 2 and the solid timber loaded in direction 2 showed a tendency to decrease the embedding strength as the dowel diameter increases, and the magnitude of the decrease was similar in these three series of tests.

- Through typical embedding stress-displacement curves, a ductile behavior was observed in CLT, standing between the behavior of solid timber loaded in directions 1 and 2 .

- For CLT, the maximum ratio between the embedding strength in direction 1 and 2 reached 32\%, for the dowel diameter of $12 \mathrm{~mm}$.

- For solid timber, the maximum ratio between the embedding strength in direction 1 and 2 attained $53 \%$, for the dowel diameter of $16 \mathrm{~mm}$.

- The CLT embedding strength in direction 1 was up to $8 \%$ lower than those for solid timber in the same direction.

- The CLT embedding strength in direction 2 was up to $26 \%$ higher than those for solid timber in the same direction.

- ANOVA results showed no statistical evidence that the mean embedding strengths of CLT and solid timber are different, except for the results obtained when the loads were applied in direction 2 and the dowel diameter was $16 \mathrm{~mm}$.

- The equation proposed by KENNEDY et al. [31] shows the best fit with the experimental results of this research, both for loads in directions 1 and 2.

- The equations proposed on the literature for the embedment strength of dowel-type fasteners on the CLT panels could be reviewed, as discussed in section 4.4.

- The failure modes observed in the three-layer CLT specimens were the same as those observed in solid timber, and it was concluded that the rupture happens individually in each layer.

To future research, it is suggested that tests with three-layer CLT be performed, however considering a larger range of commercial lamellar thicknesses, as well as CLT tests with a larger number of layers. It is also rec- 
ommended a research considering different layers thicknesses to analyze the fit of KENNEDY et al. [31] equation in this cases.

\section{ACKNOWLEDGEMENTS}

The authors gratefully acknowledged the Coordenação de Aperfeiçoamento de Pessoal de Nível Superior Brasil (CAPES) for finance in part this study (Finance Code 001). The authors are also thankful to Jowat Adhesives industry for providing the adhesive.

\section{BIBLIOGRAPHY}

[1] RINGHOFER, A., BRANDNER, R., BLASS, H.J., Cross laminated timber (CLT): Design approaches for dowel-type fasteners and connections, Engineering Structures, pp. 1-13, 2018.

[2] UNECE/FAO, Annual Market Review 2016-2017 Forest Products, Genebra, United Nations Publication, 2017.

[3] AMORIM, S.T.A., MANTILLA, J.N.R., CARRASCO, E.V.M., A madeira laminada cruzada: Aspectos tecnológicos, construtivos e de dimensionamento, Revista Materia, v. 22, 2017.

[4] HASSANIEH, A., VALIPOUR, H.R., BRADFORD, M.A., Load-slip behaviour of steel-cross laminated timber (CLT) composite connections, Journal of Constructional Steel Research, v. 122, pp. 110-121, 2016.

[5] BRANDNER, R., FLATSCHER, G., RINGHOFER, A., et al., Cross laminated timber (CLT): overview and development, European Journal of Wood and Wood Products, v. 74, n. 3, pp. 331-351, 2016.

[6] GSELl, D., FELTRIN, G., SCHUBERT, S., et al., Cross-Laminated Timber Plates: Evaluation and verification of homogenized elastic properties, Journal of Structural Engineering, v. 133, n. 1, pp. 132-138, 2007.

[7] SANDHAAS, C., VAN DE KUILEN, J.-W.G., BOUKES, J., et al., "Analysis of X-lam panel-to-panel connections under monotonic and cyclic loading," in In: CIB-W18, 42, 2009, 2009, n. August.

[8] POPOVSKI, M., SCHNEIDER, J., SCHWEINSTEIGER, M., "Lateral load resistance of cross-laminated wood panels," in In: World Conference on Timber Engineering, 2010, Riva del Garda, 2010.

[9] GAVRIC, I., FRAGIACOMO, M., CECCOTTI, A., Strength and deformation characteristics of typical X-lam connections, World Conference on Timber Engineering 2012, WCTE 2012, v. 2, pp. 146-155, 2012.

$[10]-$ Cyclic behaviour of typical metal connectors for cross-laminated (CLT) structures, Materials and Structures, v. 48, n. 6, pp. 1841-1857, 2015.

[11] HOSSAIN, A., DANZIG, I., TANNERT, T., Cross-Laminated Timber shear connections with doubleangled self-tapping screw assemblies., Journal of Structural Engineering, v. 142, n. 11, pp. 1-9, 2016.

[12] IZZI, M., FLATSCHER, G., FRAGIACOMO, M., et al., Experimental investigations and design provisions of steel-to-timber joints with annular-ringed shank nails for Cross-Laminated Timber structures, Construction and Building Materials, v. 122, pp. 446-457, 2016.

[13] IZZI, M., RINALDIN, G., POLASTRI, A., et al., A hysteresis model for timber joints with dowel-type fasteners, Engineering Structures, v. 157, n. July 2017, pp. 170-178, 2018.

[14] DONG, W., WANG, Z., ZHOU, J., et al., Embedment strength of smooth dowel-type fasteners in crosslaminated timber, Construction and Building Materials, v. 233, p. 117243, 2020.

[15] BROWN, J.R., LI, M., Structural performance of dowelled cross-laminated timber hold-down connections with increased row spacing and end distance, Construction and Building Materials, v. 271, p. 121595, 2021.

[16] JOHANSEN, K.W., Theory of timber connections, International Association of Bridge and Structural Engineering, v. 9, pp. 249-262, 1949.

[17] RAMMER, D.R., WINISTORFER, S.G., Effect of moisture content on dowel-bearing strength, Wood and Fiber Science, v. 33, n. 1, pp. 126-139, 2001.

[18] HÜBNER, U., BOGENSPERGER, T., SCHICKHOFER, G., "Embedding strength of european hardwoods," in In: CIB-W18, 41, 2008, Saint Andrews, 2008.

[19] SJÖDIN, J., SERRANO, E., ENQUIST, B., Anexperimental and numerical study of the effect of friction in singledowel joints, Holz als Roh - und Werkstoff, v. 66, n. 5, pp. 363-372, 2008.

[20] SANDHAAS, C., RAVENSHORST, G.J.P., BLASS, H.J., et al., Embedment tests parallel-to-grain and ductility aspects using various wood species, European Journal of Wood and Wood Products, v. 71, n. 5, pp. 599-608, 2013.

[21] EUROPEAN COMMITEE FOR STANDARDIZATION, EN 1995 1-1: General - common rules and rules for buildings (Eurocode 5)., Bruxelas, 2004. 
[22] WHALE, L.R.J., SMITH, I., LARSEN, H.J., "Design of nailed and bolted joints proposals for the revision of existing formulae in draft Eurocode 5 and CIB Code," in In: CIB-W18, 20, 1987, Dublin, 1987.

[23] EHLBECK, J., WERNER, H., "Softwood and hardwood embedding strength for doweltype fasteners," in In: CIB-W18 Timber Structures, 1992, pp. 25-7-2.

[24] AMERICAN NATIONAL STANDARDS INSTITUTE/AMERICAN WOOD COUNCIL, NDS: National design specification for wood construction., Washington, 2015, p. 200.

[25] WILKINSON, T., Dowel bearing strength, USDA Forest service Res. Paper FPL- RP-505, pp. 1-9, 1991.

[26] SAWATA, K., YASUMURA, M., Determination of embedding strength of wood for dowel-type fasteners, Journal of Wood Science, v. 48, n. 2, pp. 138-146, 2002.

[27] BLERON, L., DUCHANOIS, G., Angle to the grain embedding strength concerning dowel type fasteners, Forest Products Journal, v. 56, n. 3, pp. 44-50, 2006.

[28] BLASS, H.J., UIBEL, T., Tragfähigkeit von stiftförmigen Verbindungsmitteln in Brettsperrholz, Karlsruhe, Universität Karlsruhe (TH), 2007.

[29] UIBEL, T., BLASS, H.J., "Load carrying capacity of joints with dowel type fasteners in solid wood panels," in International Council for Research and Innovation in Building and Constrcution, 2006, v. 39, n. August, pp. 1-11.

[30] UIBEL, T., BLASS, H.J., Edge Joints with Dowel Type Fasteners in Cross Laminated Timber, n. August, 2007.

[31] KENNEDY, S., SALENIKOVICH, A., MUNOZ, W., et al., "Design equations for dowel embedment strength and withdrawal resistance for threaded fasteners in CLT.," in In: World Conference on Timber Engineering, 2014, Quebec, 2014.

[32] DONG, W., LI, Q., ZHANG, H., et al., Embedment Strength of Cross-Laminated Timber for Smooth Dowel-type Fasteners, MATEC Web of Conferences, v. 275, n. 201 9, p. 01020, 2019.

[33] DONG, W., LI, Q., WANG, Z., et al., Effects of embedment side and loading direction on embedment strength of cross-laminated timber for smooth dowels, European Journal of Wood and Wood Products, $\mathrm{n}$. $0123456789,2020$.

[34] UIBEL, T., BLASS, H.J., "Joints with Dowel Type Fasteners in CLT Structures Test material," In: Harris, R., Ringhofer, A., and Schickhofer, G. (eds), Focus Solid Timber Solutions - European Conference on Cross Laminated Timber (CLT), 2nd ed., The University of Bath, pp. 119-134, 2014.

[35] AMERICAN SOCIETY FOR TESTING AND MATERIALS, D5764-97a: Standard test method for evaluating dowel-bearing strength of wood and wood-based products., West Conshohocken, 2018.

[36] ASSOCIAÇÃO BRASILEIRA DE NORMAS TÉCNICAS, NBR 7190 - Projeto de estruturas de madeira., Rio de Janeiro, 1997, p. 107.

[37] PEREIRA, M.C. de M., CALIL JUNIOR, C., Strength and stiffness of cross laminated timber (CLT) panels produced with pinus and eucalyptus: Experimental and analytical comparisons, Revista Materia, v. 24, n. 2, 2019.

[38] OTTENHAUS, L., LI, M., SMITH, T., et al., Overstrength of dowelled CLT connections under monotonic and cyclic loading, Bulletin of Earthquake Engineering, v. 16, n. 2, pp. 753-773, 2018.

[39] SCHOENMAKERS, J.C.M., JORISSEN, A.J.M., LEIJTEN, A.J.M., Evaluation and modelling of perpendicular to grain embedment strength, Wood Science and Technology, v. 44, n. 4, pp. 579-595, 2010.

[40] SANTOS, C.L., DE JESUS, A.M.P., MORAIS, J.J.L., et al., A comparison between the EN 383 and ASTM D5764 test methods for dowel-bearing strength assessment of wood: Experimental and numerical investigations, Strain, v. 46, n. 2, pp. 159-174, 2010.

[41] TUHKANEN, E., MÖLDER, J., SCHICKHOFER, G., Influence of number of layers on embedment strength of dowel-type connections for glulam and cross-laminated timber, Engineering Structures, v. 176, pp. 361-368, 2018.

[42] OTTENHAUS, L.M., LI, M., SMITH, T., et al., Overstrength of dowelled CLT connections under monotonic and cyclic loading, Bulletin of Earthquake Engineering, v. 16, pp. 753-773, 2018.

[43] BRITISH STANDARDS, EN 383: Timber Structures - Test methods - Determination of embedment strength and foundation values for dowel type fasteners., Bruxelas, BSI, 2007.

[44] SJÖDIN, J., SERRANO, E., ENQUIST, B., Experimentelle und Rechnerische Untersuchung des Einflusses von Reibung in Verbindungen mit einem Stabdübel, Holz als Roh - und Werkstoff, v. 66, n. 5, pp. 363-372, 2008.

[45] NAKASHIMA, S., KITAMORI, A., MORI, T., et al., "Evaluation of tensile performance of drift pin joint of cross laminated timber with steel inserted plate," in In: World Conference on Timber Engineering, 2012, Auckland, 2012.

[46] RAMMER, D.R., "Effect of Moisture Content on Nail Bearing Strength.," U.S. Department of 
Agriculture, Forest Service, Forest Products Laboratory, Research Paper (FPL-RP-591)., Madison, p. 22, 2001.

\section{ORCID}

Bruna Bernardi Maia

https://orcid.org/0000-0002-3829-8610

José Luiz Miotto

https://orcid.org/0000-0003-3913-6522

Jorge Luís Nunes de Góes

https://orcid.org/0000-0001-5810-4708 